\title{
STUDENT NURSES' EXPERIENCE OF A SYSTEM OF PEER GROUP SUPERVISION AND GUIDANCE
}

\section{Diana du Plessis}

D Cur (Midwifery \& Neonatology)

Senior Lecturer, Department of Nursing Science, Rand Afrikaans University

Correspondence: dwdp@edcur.rau.ac.za

Keywords: accompaniment; clinical learning environment; contract tutor; guidance; peer group supervision; student

\section{ABSTRACT}

Peers are important in self- or group assessment as they provide learners with a useful perspective on their performance. They can do this in ways that are more informal and less threatening in many more circumstances than teachers can (Chabeli, 2001a:13). "Learning is enhanced through maximising the opportunities for learners to discuss their work with others. The question is, how can the peer group be used most effectively?" (Boud, 1995:200). A system of peer group supervision and accompaniment for student nurses has been in place at a university in Gauteng, South Africa, since 1989. Up to 1999 the junior students were accompanied in the clinical practice by fourth-year nursing students. The senior student provided the junior learner with valuable learning opportunities whilst simultaneously gaining experience and skills in the process of evaluating another's practice. During the revision of the curriculum in 1999, the fourth-year students expressed themselves negatively towards peer group guidance, due to practical and other reasons. However, feedback from the first-year students indicated that they experienced the system positively. Recommendations were made to change the system in order to eliminate the negative aspects and after careful consideration and programme changes, implemented in 2001. It therefore became necessary to evaluate the revised system of peer group supervision and guidance for effectiveness. A qualitative, descriptive, explorative and contextual research design was utilised to conduct this research in order to obtain information that would facilitate understanding of the students' experiences of peer group supervision and guidance within the clinical learning environment. A purposeful convenient sampling was done from two populations of student nurses at a specific university in Gauteng. Second- and third-year nursing students were used in the study. Naïve sketches were used as a method of data gathering. One central question was asked: "How did you experience the new system of peer group supervision and guidance?" Focus group interviews were held with both groups to verify the findings and triangulate data. Two themes resulted from the analysis of the naïve sketches: positive and negative experiences of peer group supervision and guidance. A literature control was done to verify the results and the experiences were discussed during a focus group in an atmosphere of mutual respect, trust, enthusiasm, empathy and justice. The themes that were identified indicated that certain elements motivated nursing students to participate. Negative elements were identified that could be eliminated. Recommendations for the implementation of a system of peer group supervision and guidance were made.

\section{OPSOMMING}

Portuurgroeplede is belangrik in self- of groepassessering omdat hulle die leerders van nuttige inligting en perspektief oor hulle vordering voorsien. Hulle kan dit doen op wyses wat meer informeel en minder bedreigend is as assessering deur die dosent (Chabeli, 2001a:13). "Learning is enhanced through maximising the opportunities for learners to discuss their work with others. The question is, how can the peer group be used most effectively?" (Boud, 1995:200). 'n Stelsel van portuurgroep-toesighouding en -begeleiding is reeds in plek by ' $n$ universiteit in Gauteng, Suid-Afrika sedert 1989. Tot 1999 is die junior studente in die kliniese praktyk deur vierdejaarverpleegkundestudente begelei. Die senior studente het die junior studente met waardevolle leergeleenthede toegerus 
terwyl hulle terselfdertyd vaardighede verkry het in die proses van evaluering van ander persone se kliniese praktykvoering. Tydens die evaluering van die kurrikulum gedurende 1999, het die vierdejaarstudente hulle negatief uitgespreek teenoor portuurgroepbegeleiding, weens praktiese en ander redes. Terugvoer deur die eerstejaarstudente het egter aangedui dat hulle die portuurgroepbegeleiding positief beleef het. Aanbevelings is gemaak om die stelsel te verander om die negatiewe aspekte uit te skakel. Na noukeurige oorweging en programaanpassings, is die nuwe stelsel van portuurgroeptoesighouding en -begeleiding in 2001 geïmplementeer. Dit het dus nodig geword om die hersiende stelsel van portuurgroeptoesighouding en -begeleiding te evalueer vir effektiwiteit. ' $n$ Kwalitatiewe, beskrywende, ondersoekende en kontekstuele navorsingsontwerp is gebruik om hierdie navorsing uit te voer. Die doel was om inligting in te samel wat begrip van die student se ervaring van portuurgroeptoesighouding en -begeleiding in die kliniese omgewing sal fasiliteer. ' $n$ Doelgerigte gerieflikheidsteekproef van twee populasies van verpleegkundestudente is van 'n universiteit in Gauteng bekom. Tweedejaar- en derdejaarstudente is in die studie gebruik. Naïewe sketse is as metode van data-insameling gebruik. Een sentrale vraag is gevra: "Hoe het u die nuwe stelsel van portuurgroep-toesighouding en -begeleiding beleef?" Fokusgroeponderhoude is met albei groepe gevoer om die bevindinge te verifieer en die data te trianguleer. Twee temas is uit die analise van die naïewe sketse verkry naamlik positiewe en negatiewe ervarings van portuurgroeptoesighouding en -begeleiding. ' $n$ Literatuurkontrole is gedoen om die resultate te verifieer en die belewenisse is met die groepe in 'n atmosfeer van wedersydse vertroue, respek, entoesiasme, empatie en gelykheid bespreek. Die geïdentifiseerde temas dui aan dat sekere elemente verpleegkundestudente motiveer om deel te neem. Negatiewe elemente is geïdentifiseer wat elimineer kan word. Aanbevelings vir die implementering van 'n stelsel van portuurgroeptoesighouding en -begeleiding is gedoen.

\section{BACKGROUND AND RATIONALE}

Clinical supervision, guidance and accompaniment of nursing students in the clinical practice form an integral part of their personal and professional development (Klopper, 2000:106-107; McSherry, Kell \& Pearce, 2002:31). Through clinical supervision and accompaniment the nursing students learn to act independently as professional practitioners who deliver a high standard of quality nursing care. The theoretical knowledge learned in the classroom is applied in the practical situation, and under the supervision of a more senior nurse skills and competencies are practised. A supportive relationship, formed between equals and clinical expertise by supporting staff, helps to prevent problems in busy, stressful practice settings. "(Although) clinical supervision is still regarded with suspicion by many nurses.... there are no doubt that when it is properly implemented, it can have a profound and positive impact on the standards of care" (Cole, 2002:22).

Although clinical supervision and guidance was hailed as the solution of many nursing problems in the early 1990 's the reality remains that it is not implemented in the clinical setting, mainly because of a lack of time and expense (Cole, 2000:22; Kell, 2002:29; McSherry et al. 2002:31). Time is needed to develop and implement the system and the cost incurred when professional nurses take time out of the working day to supervise and guide student nurses, is also viewed cynically (McSherry et al. 2002:31). Clinical supervision is thus regarded as the function of the university lecturer, who is seen as blaming staff if things go wrong (McSherry et al. 2002:31). However, direct observation of the learner's performance helps to diagnose the progress of the learner (Chabeli, 2001b:248).

In the health system in South Africa clinical supervision and guidance are often seen as a luxury rather than a necessity. Research has furthermore indicated that clinical supervision and guidance can only be successful when it is voluntary (Bassett, 1999; Faugier \& Butterworth, 1994). "It is also totally dependent on the quality and quantity of supervisors and they are often thin on the ground" (Cole, 2002:24). Nursing students often experience uncertainty and anxiety in the clinical settings due to the unavailability and inaccessibility of staff due to time constraints, lack of awareness among senior professionals regarding the needs and problems of student nurses and conflicting expectations of the lecturers and clinical nursing personnel (Carlson, Kotze \& Van Rooyen, 2003:30). 
Peer tutoring involves the teaching of one student by another. The student may be at the same level of training or senior to the group in experience (Chabeli, $2001 \mathrm{~b}: 281$ ). Peer tutoring is an effective method of fostering positive interaction between learners of different cultural backgrounds and for improving achievement, interpersonal relationships and attitudes towards the clinical environment (Biehler \& Snowman, 1991:257-258). To deny the existence or importance of peer group teaching shows complete lack of understanding of the unit learning-teaching situation in nursing (Mellish, Brink \& Paton, 1998:159). In order to overcome the lack of clinical supervision and guidance in the clinical setting, a system of peer group supervision and guidance for student nurses was implemented at a university in Gauteng, South Africa, in 1989. Working with someone who is more experienced in particular settings, yet regarded as "at almost the same level of practice", helps junior students to develop their knowledge and skills. Up to 1999 the junior students (first- and second-year students) were accompanied in the clinical setting by fourth-year student nurses. A formal programme with explicit instructions was followed where the senior student provided the junior learner with valuable learning opportunities. The students would share and learn from past and current experiences in a nonthreatening environment (McSherry et al. 2002:31).

An unplanned benefit of the system of peer group supervision and guidance included that the senior students were gaining experience and skills in evaluating other students' practice. The fourth-year students were expected to supervise, guide, evaluate and assess the juniors' performance with evaluation instruments they compiled themselves for particular psychomotor skills. This formed part of the senior student's practical requirements for nursing education to develop teaching skills.

Peer group supervision and guidance are important in self- or group assessment as they provide learners with a useful perspective on their performance. They can do this in ways that are more informal and less threatening in many more situations than teachers can (Chabeli, 2001a:13). The benefits of effective supervision and guidance include that the junior nursing students will be more skilled by the time they enter the curative hospital setting. They reflect on their own and others' strengths and weaknesses to develop and enhance practice (Hencliff in Joubert, 1989:9596). It furthermore promotes an ethos of openness and honesty in the practice setting, promoting a person's ability to review practice and make changes when problems are encountered (McSherry et al. 2002:31).

Since 1989-1999 the sessions intended for peer group supervision and guidance were scheduled on the programme during the second semester. An annual evaluation and feedback session provided information necessary for curriculum revision and modification of the programme. The clinical supervision had to show that it did not only make students "feel better or happier" but also made a difference in their ability to adjust to the clinical setting.

During the annual evaluation and feedback session of 1999, the fourth-year student nurses expressed themselves negatively towards peer group guidance. They indicated that the fourth year was extremely busy, as it included Psychiatric Nursing Science, Nursing Education and Administration as well as a research project. This left them with too little time for effective peer group supervision and guidance. They furthermore expressed no interest in supervising junior students. The senior students' recommendations to change the system of peer group supervision and guidance in order to eliminate the negative aspects included the following:

- Interested students must apply for peer group supervision and guidance. Cole's (2002:24) statement that clinical supervision can be successful only when it is voluntary, supports this.

- A selection process of peer group supervisors must be implemented by the lecturers who coordinate the programme.

- Interested students must be financially compensated for their time.

Feedback from the first-year students indicated however, that they experienced the system positively. They viewed the final-year students as role models and admired them. They furthermore saw the senior students as "one of their own" and felt comfortable in their presence. The senior students motivated them and the junior students experienced them as their own support persons. 
Despite the negative comments by the final-year students, the members of the Department of Nursing were convinced that the system of peer group supervision and guidance was necessary for the professional development of student nurses. After careful consideration and programme changes, a new system of peer group guidance was planned. The new system included:

The fourth-year student nurses would still participate in peer group supervision and guidance of first-year students during the second semester. In this way they would orientate the new hospital entrées and allow them to practise the basic skills taught during the orientation programme, similar to various orientation programmes for prospective nursing students. (First-year students only enter the curative hospital setting in the first semester of their second year). This would furthermore allow senior students to practise their ward administration, leadership and teaching skills.

- The co-ordinator of the peer group system would compile all evaluation instruments and distribute them to the senior students for use. This would reduce the senior students' workload.

- Interested third-year students would be recruited for peer group supervision and guidance of second-year students during the first semester, as they enter the hospital system.

During 2001 the first interested third-year student nurses were recruited for peer group supervision and guidance. The only pre-requisite was that they should have passed all their second-year subjects. Twelve (12) students were appointed per contract (hence called contract tutors) and salaries and duty-hours were discussed and approved by the Head of the Department. It was envisaged that this system would make the transition of first-year nursing students from preventative to curative settings easier.

\section{PROBLEM STATEMENT, RESEARCH QUESTION AND OBJECTIVES}

The system of peer group supervision and guidance at a specific university in Gauteng was changed from a compulsory system to a system where interested students were contracted to guide and accompany junior students within a hospital setting. The new system was implemented in 2001 and the students' experiences of the new system were not yet determined. It there- fore became necessary to evaluate the new system of peer group supervision and guidance. The researcher asked the following question: "How did you experience the system of peer group supervision and guidance?"

The study had the following objective:

To explore and describe how second-year student nurses and contract tutors at a specific university in Gauteng experienced the voluntary system of peer group supervision and guidance.

\section{DEFINITION OF TERMINOLOGY}

Peer group supervision and guidance: Within the context of this article, this is seen as directed assistance and support by peers in order to assist the junior student to become a competent secondyear nursing practitioner. It furthermore refers to planned and deliberate intervention by the contract tutor and includes all those activities that occur in a planned fashion according to a set programme (Klopper, 2000:16).

Contract tutors: This refers to third-year nursing students who had passed all their second-year subjects and volunteered to supervise and guide second-year nursing students at a given time. The tutors receive a financial incentive.

Clinical learning environment: This refers to the environment in which students perform skills related to the needs of patients (Klopper, 2000:16).

Student: This refers to an individual who is following the Baccalaureate Curationis programme at die Department of Nursing of a University in Gauteng. These individuals are currently in their second year of nursing studies.

\section{RESEARCH DESIGN AND METHOD}

A qualitative, descriptive, explorative and contextual research design was utilised to conduct this research (Mouton \& Marais, 1992:103-169). The focus was to obtain information that would facilitate understanding of the students' experiences of peer group supervision and guidance within the clinical learning environment. 


\section{Sampling}

Purposeful convenient sampling was done where the researcher consciously selected certain subjects from two populations at a specific university in Gauteng: (a) all the second-year nursing students; (b) interested contract tutors from the third-year nursing students (Burns \& Grove, 1999:475).

\section{Description of the sample}

- The sample consisted of twelve (12) interested contract tutors who passed all their second-year subjects and 32 second-year nursing students who were purposively selected (Burns \& Grove, 1994:56) to participate in this study. The co-ordinator of the programme compiled an alphabetical class list of the second-year students and allocated the contract tutor to each one. Second-year students were free to choose a different tutor after discussions with the co-ordinator.

- All students were fluent in Afrikaans and English and of different cultural groups. Students were allocated regardless of language preference or cultural group.

- All students gave written permission to be included in the study.

- Male as well as female students were included.

\section{Training of the tutors}

The tutors were trained by the co-ordinator of the programme that had weekly meetings, demonstrations and practical sessions with them, preparing them for the following session. These students completed the practical requirements of their studies the previous year and were thus familiar with the requirements and techniques. Additional information, booklets and articles were discussed and handed to the tutors. Model questions and answers were supplied and the tutors each received an "Information Guide for Tutors". This information guide was compiled by the coordinator of the programme. After each session, the tutors and co-ordinator of the programme met to discuss problems or issues pertaining to that particular session.

\section{Approach used in the peer group supervision and guidance programme}

The content of the peer group programme was based on the second-year Fundamental Nursing Science curriculum, which focussed on the basic needs of patients. It included basic nursing skills most commonly required from student nurses in their second year of studies. The nursing students had the theoretical module on example the Monday, the practical demonstration of relevant skills on the Tuesday and the peer group supervision and guidance on the Thursday. The content was similar in all respects, reinforcing the application of theory and practice. Depending on the content, the tutors would demonstrate psychomotor skills, assess patients, compile case studies or nursing care plans or render nursing care to patients in the clinical area. They worked on a "see-one-do-one" principle, where the student nurses would observe first, (example wound care) practice, and then demonstrate under the watchful eyes of their tutors, their competency. They identified medical-legal hazards, ethical issues and did an audit of patient records and medical prescriptions. The content gradually progressed from simple to more complex tasks.

\section{Data collection}

Naïve sketches were used as a method of data gathering, where the students were requested to write down their experiences in an open and honest fashion (Giorgi, 1985:1, 8). These short descriptions were written anonymously and it was hoped that the students would use their freedom of speech to be open and honest about their positive and less positive experiences.

One central question was asked: "How did you experience the system of peer group supervision and guidance?"

Focus group interviews were held with both groups to verify the findings and to add information, if needed. The interviewer was a fourth-year nursing student who had recently completed a course in research methodology and had successfully completed an assessment of her interviewing skills. The interviews were audiotaped and transcribed for analysis. Field notes were taken in order to document the non-verbal communication, the ease with which the interview was done, as well as the subjective interpretations of the 
interviewer.

\section{Data analysis}

Data analysis was done according to Tech's descriptive method (in Creswell, 1994:154-156) of qualitative data analysis. The following steps were utilised:

- Reading through the naïve sketches to form an idea of the story line.

- Reading the naïve sketches a second time to think about the underlying meaning.

- The next step was to write notes in the margin about the underlying meanings.

- Similar topics were then clustered together under topics. From these topic categories and subcategories were formed.

- The categories were revised until final categories and sub-categories were formulated.

- Interviews were transcribed verbatim and analysed by the researcher and an independent coder. Interviews were analysed for the emergence of themes prevalent amongst all participants. Data were reduced until the central storyline emerged from the raw data.

- An independent coder, experienced in the field of qualitative research, with special interest in Psychiatric Nursing Science, analysed the data separately from the researcher and after discussions and consensus between the researcher and the coder, the identified themes were finalised.

- A literature control was done to verify the research study and results according to Morse and Field (1996:106) in order to formulate guidelines. The guidelines were discussed with a clinical specialist in Psychiatric Nursing and Research.

\section{Trustworthiness}

Measures to ensure trustworthiness were applied. Guba's model (in Krefting, 1991:215-222) included credibility, transferability, dependability and confirmability. The activities in achieving them were prolonged engagement in the analysis of the naïve sketches, keeping reflective notes, member checking by literature control, peer examination and member control by means of a group discussion of all the involved students. Transferability was achieved by purposive sampling, description of dense methodology and literature control. Dependability was achieved by a complete description of the methodology, including literature control to maintain clarity and the use of an independent coder skilled in the field of research.

\section{Ethical measures}

Ethical measures included informed consent of the students to participate in the study, anonymity, ensuring confidentiality and providing all students with the results (DENOSA, 1998:1-8). The contract tutors had the right to refuse participation and withdraw from the study at any given time and the students had the right to choose a different contract tutor. All students, however, persevered throughout the study.

\section{DISCUSSION OF RESULTS}

The discussion of the findings will be based on Table 1 , which gives an overview of the main category/subcategories with direct quotations from the role players. A literature control will thereafter be integrated with classical sources.

\section{FINDINGS}

\section{Positive experiences}

\section{Positive experience related to integration of theory and practice}

Practice experience is a vital aspect of learning in nursing and education and the initial placement of students in a clinical environment produces greater anxiety for students than at any other stage of their training (Parkes, 1985:950; Jones \& Johnston, 1997:476).

The respondents experienced the integration of theory and practice as positive because they obtained insight in the physical, psychological and social needs of the patient, as they rendered basic nursing care. They had the opportunity to render basic nursing care to the patient as a holistic being. The students felt they had time to practice skills, which made them feel more competent, and the tutors were willing to engage longer than the scheduled allocated period. This was reflected in the following remarks: "I think the seniorthird year system really worked well. Theory and practical were really correlated". "It motivated me to 
Table 1: Overview of main categories and sub-categories

\begin{tabular}{|c|c|}
\hline MAIN CATEGORY & SUB-CATEGORIES \\
\hline $\begin{array}{l}\text { 1. Positive experiences of peer group } \\
\text { guidance: } \\
\text { - The students experienced the new system } \\
\text { of peer group guidance as positive and } \\
\text { effective. }\end{array}$ & 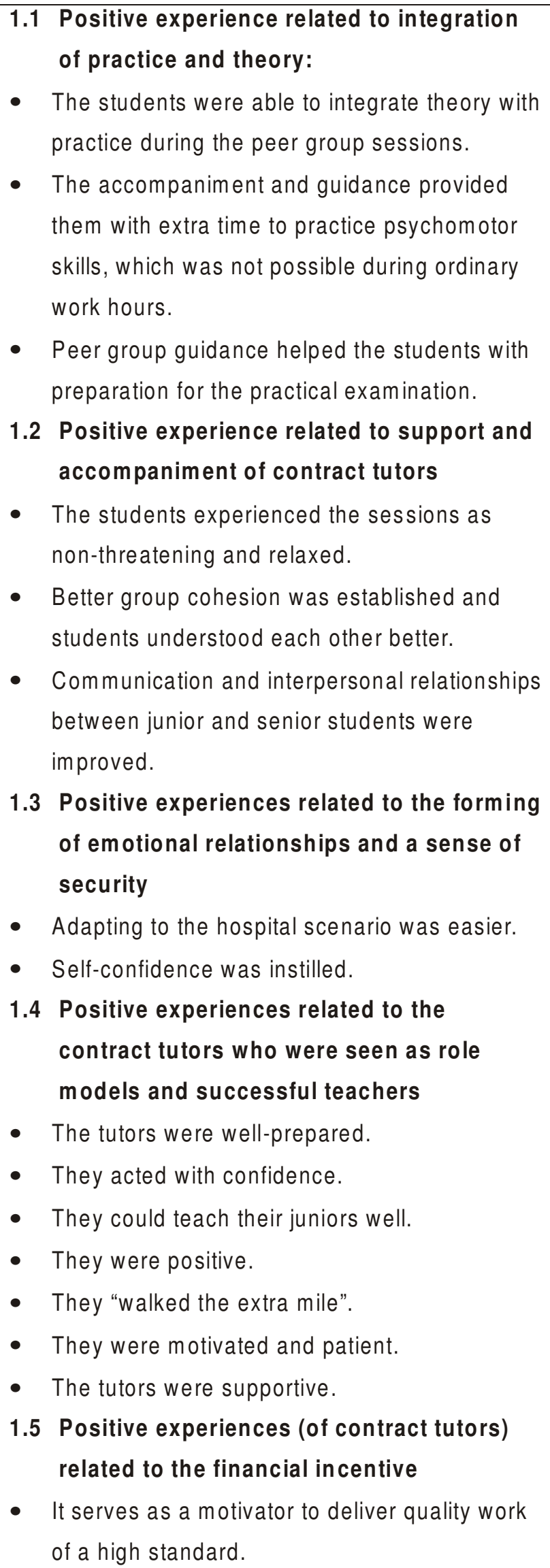 \\
\hline
\end{tabular}




\begin{tabular}{|c|c|}
\hline $\begin{array}{l}\text { 2. Negative experiences related to peer } \\
\text { group guidance }\end{array}$ & $\begin{array}{l}\text { 2.1 Negative experiences related to scheduling } \\
\text { of the programme: } \\
\text { - Students need extra time to dress and prepare } \\
\text { for the sessions which follow their ordinary } \\
\text { class periods on campus. } \\
\text { - Careful consideration of the day and time of } \\
\text { the sessions must be taken into account when } \\
\text { planning. } \\
\text { 2.2 Negative experiences related to unsure } \\
\text { and ill-prepared tutors } \\
\text { - Some tutors were not as competent as others, } \\
\text { and not as motivated. } \\
\text { - Some tutors were not role models. } \\
\text { - Students perceived the tutors as merely } \\
\text { performing a function, motivated by the } \\
\text { financial incentive. } \\
\text { 2.3 Contract tutors experienced problems with } \\
\text { discipline and authority } \\
\text { - Some students were perceived as being } \\
\text { disrespectful and ill-prepared. } \\
\text { 2.4 The contract tutors experienced a lack of } \\
\text { structure } \\
\text { - Too much time was spent on certain } \\
\text { competencies and content. } \\
\text { subsequently done in English. } \\
\text { the Englity related to their own inputs, } \\
\text { - Racial, language and personality problems } \\
\text { - }\end{array}$ \\
\hline
\end{tabular}


care better for this particular patient. It was really wonderful to practice the things I was taught in the orientation on a real patient". "I had time to practice the things I could not do at first. The seniors helped us with preparation for the practical examination to integrate theory, they were there on that day, kept us calm and just were present'.

When students work in the clinical environment, they must become familiar with the general functioning of the ward, and it is thus expected from them to perform nursing skills previously demonstrated in a simulated environment. This may cause anxiety and insecurity. If the students have the opportunity to nurse patients in a clinical environment under the guidance and supervision of peers, they would be more motivated because they gain experience in competencies when they are allowed to perform certain procedures on patients (Chabeli 2001b:122, 135-138; Du Plessis 1993:115-117). Knowledge will be more easily recalled because of this personal contact. The students felt they were able to meet the needs of patients due to the system of peer group guidance and supervision.

\section{Positive experience related to support and accompaniment of contract tutors}

One of the biggest challenges the student nurses have is to fit in with the social environment of the clinical field and to be accepted by their peers and superiors when doing their practicals (Carlson, Kotze \& Van Rooyen, 2003:35). The support by the more senior students was very positively experienced, as the junior students felt comfortable in their presence. They were of the opinion that the tutors were "their own" and could understand them better. They felt assisted, educated and supported to achieve professional abilities. These students were previously guided in their first year by fourth-year student nurses for a very limited period during an "orientation to the workplace" session: "It made a big difference with the third-years. Communication is now easier and better". "The communication is much better. They are the same as us". "The degree students started to work together". "I learned a lot from my senior to make me a better practitioner". "The seniors helped us with preparation for the practical examination, in order to integrate the theory, they were there and kept us calm".

Van den Berg (1984:98) and Knowles (in Du Plessis,
1993:17) support these experiences and relate it to the fact that the interpersonal relationship between peers, is symmetrical and students accept co-responsibility for learning in a system of mutual trust. "It helps people to develop their personal qualities in relation to their roles. It helps them to feel more confidence about having a difficult conversation with somebody" (Cole, 2002:23). McSherry et al. (2002:23), however, are of the opinion that the group may learn to rely too heavily on one person (the contract student), adding to their workload.

\section{Positive experiences related to the forming of emotional relationships and a sense of security}

The attitudes of peers and superiors influence the perception the students have of themselves. These students came from a sheltered environment in their first year with regular contact with less sick individuals in clinics and found themselves in a completely different world with new experiences related to human suffering. The second-year students had to enter the unknown curative hospital system for the first time in their training and without proper supervision and guidance, this has all the potential to cause uncertainty and anxiety.

They bonded with the tutors, formed emotional relationships and expressed a sense of security whenever they were confronted with situations they have never experienced before. They verbalised their feelings of competency, achievement and selfconfidence. The following statements reflect this: "As a second-year, I gained more self-confidence. My selfconfidence really improved during peer group sessions". "They helped us to adapt to the new environment'. "They were there and kept us calm". "I made mistakes which made me feel bad but I will never repeat them again".

These experiences of emotional well-being is supported by research done by Botes (1986:140) and $\mathrm{Nel}(1986: 16)$ who found that the world of nursing is foreign to new practitioners, and although they experience hope and anticipation, they present with their own needs and incapability's - for this they need the support and help of experienced and trustworthy persons. The group provides a safe and secure environment in which they are free to unburden themselves without being judged (Mellish \& Brink, 1990:53). 
"They can be astonishingly open and honest about their own and other's faults. Sometimes there are tears. But by talking openly and confidentially they are reaching a point of deeper self-awareness" (Cole, 2002:22). Koopman (in Cole, 2002:23) states that clinical supervision by peers was "an anchor in a sea of change".

\section{Positive experiences related to the contract tutors who were seen as role models and successful teachers}

Most of the respondents respected the fact that the tutors were role models who not only had the psychomotor skills needed for nursing, but also demonstrated thorough knowledge, values and norms. The following statements reflect this: "The preparation and demonstrations were of the highest quality". "... and it was good that we were able to work with competent third years. It helped us a great deal". "They had good interpersonal skills and the workload was shared". "They listened to our concerns". "They had enough time for us and could teach us on the spot if something happened".

The characteristics of a successful peer group supervisor must include aspects like good interpersonal relationships, availability and accessibility, respect, responsibility and must respect the students by being on time for sessions. Successful peer group supervisors motivate and persevere regardless of time restrictions (Armstrong, 1988:492; Botes, 1986:139; Nel, 1986:17; Mellish, Brink \& Paton, 1998:71-77).

\section{Positive experiences by the tutors related to the financial incentive}

The contract tutors experienced the "salary" they received in a very positive manner. They felt it motivated them even more to deliver a high standard of teaching and supervision. The following statements reflect this standpoint: "I think the payment is a good idea, as it serves as an extra motivation to render a better service". "The fee-for-service must please continue: students need extra money". "The salary we received was a good motivator and I can recommend it'.

Financial support for services rendered can be found in Hellriegel, Jackson, Slocum and Staude (1999:261) who maintain that financial rewards for time, skills and effort motivates a person to achieve the businesses' goals, in this context, good quality nursing care. Kell (2002:29) however, is of the opinion that clinical supervision and guidance should form part of a normal day's work thus indicating that a framework for clinical supervision and guidance should be in place, rather than adding financial incentives.

\section{Negative experiences}

\section{Negative experiences related to timing and scheduling on the academic programme}

The students experienced a wide range of negative emotions primarily related to the programme schedule and timing. The following remark was made: "Please reorganise the time allocated to peer group supervision to give us more time to get to the classes. Make the peer group (sessions) longer to give us more time to practice".

Hincliff (in Joubert, 1989:95-96) identified that clinical teaching will be less effective when continuous interruptions occur during the sessions or when there is insufficient time for assimilation of information. Students with less self-confidence will take longer to achieve competency in particular procedures and more time is needed to practice the skill. Enough time is needed to assimilate content, to expand their thinking about (patient) care and to improve decisionmaking and problemsolving (Cole, 2002:23).

\section{Negative experiences related to unsure and ill-prepared tutors}

Two (2) students experienced their tutors in a less positive manner and they thought the tutors to be illprepared, unmotivated and merely performed a function for the financial incentive. They were not seen as role models and the students felt cheated because of an apparent lack of preparation for the session or the lack of skills in a particular procedure.

Students will experience confusion if a discrepancy is found between what is taught to them in simulation and what is actually implemented in the clinical environment. If the tutor thus appears uncertain, the student becomes nervous and anxious (Carlson et al. 2003:36). They felt that the tutor was indifferent towards them and proposed a strict screening process for prospective tutors. The following remarks reflect this: "All I would suggest is that the selection process must 
be adapted and more care should be taking with selecting people that are sensitive and understanding about being new in hospital". "The selection process must please be more strict and critical". "Some people were not very competent and dedicated to helping us".

Mellish, Brink and Paton (1998:71-77), Nel (1986:17) and Armstrong (1988:492) support this by stating that successful educators must be knowledgeable and dedicated. They must furthermore be able to communicate knowledge to adult learners by treating them with dignity and respect, by being up-to-date with changes and advances in the clinical setting and by creating space and time to think. They must furthermore identify individual training needs, create a no-blame culture and promote teamwork.

\section{Contract tutors experienced problems with discipline and authority}

The tutors, whom the students perceived as unsure and ill-prepared, were experiencing problems with discipline and authority. Their students did not attend sessions and neglected to communicate with the tutors in order to re-schedule. Some students did not prepare for a session by reading the theory in the prescribed textbook and wanted to be spoon-fed. The tutors felt used and perceived the students as disrespectful. This is illustrated by the following statement: "The biggest problem was that the second years did not respect you as senior student".

A valuable lesson was learned during peer group supervision and guidance, and this included that respect should be earned. Mellish, Brink and Paton (1989:22-23) describe that within each teaching situation, a discipline and authority system should be in place. Controlled informality, explicit outcomes and freedom of speech could achieve this. McSherry et al. (2002:30) list the disadvantages of peer supervision and indicate that the sessions may develop into a moaning session where a person(s) may be seen to be at fault. This in return has the potential to develop into a blame culture and may then stifle discussion.

\section{Contract students felt insecure because of a lack of structure}

Study guides and written outcomes were handed out to the tutors and they received all the evaluation forms necessary to evaluate the junior students. They still displayed feelings of insecurity. A more experienced lecturer acted as support person and attended each session for a few minutes to manage any problems, but the tutors wanted more structure, which would include memoranda for particular assignments. Some tutors felt that too much time was spent on basic nursing skills and wanted to teach the students more complex skills. The following statements reflect this: "I want to propose that a person should revise, for example, the taking of vital data and not check if the student could do it on her own". "I want more explicit guidelines on how to mark an assignment". "I was not quite sure what was expected from me".

During the interviews, contract tutors shared that because this system was a revised system, they needed someone to check on them whilst doing peer group guidance and supervision. They felt unsure and would have liked to be "checked to see if she's still on the right track".

\section{Racial, language and personality problems}

Respondents of both groups experienced conflict due to racial, language and personality problems. Because the English-speaking students could not understand Afrikaans, the whole session was done in English. One Afrikaans student objected to this and saw it as preferential treatment. She insisted that the tutor translate each sentence: "I had to translate into both languages and this wasted time". "I observed personality clashes between the third-and second-year students". "It would be better to organise groups without incidence and let the second-year swap if needed". "Students should be allocated according to language preferences".

Knowles (in Du Plessis, 1993:114) supports these findings and states that culture and other sociological factors may influence the orientation to learn in either a positive or negative manner.

\section{SUMMARY}

Data analysed from the interviews and naïve sketches indicated that the students experienced the new system of peer group guidance in a very positive manner. The second-year students felt supported and cared for in the clinical learning environment because the emotional relationships stretched beyond the actual peer group session scheduled on the programmes. The contract 
tutors even supported them without any financial incentive during the practical examination. The students identified the integration of knowledge in the practical situation as the biggest benefit of the programme. They expressed the feeling of self-confidence, which helped them to adapt in the new hospital environment. Emotional bonds and feelings of trust were formed and the students regarded the tutors as role models.

The contract tutors enjoyed the teaching and the financial reward. They experienced the sessions as a business transaction and thus prepared better.

The negative issues relate to the programme structure, planning and evaluation of students. Two second-year students felt they "missed out" because the tutor was not competent. Due to the formation of strong emotional ties with the tutor, some tutors experienced difficulties with discipline and authority and race and language issues were verbalised.

\section{LIMITATIONS OF THE STUDY}

The following limitations were identified:

- The study does not include experiences of students allocated to other state or private hospitals for clinical practice.

- Due to the contextual nature of this study, the results cannot be generalised.

- The emotional bonds that formed made the identification of negative experiences initially difficult.

\section{RECOMMENDATIONS AND GUIDELINES FOR PEER GROUP SUPERVISION AND GUIDANCE}

Due to the positive experiences of these students, the system of peer group guidance and supervision should continue. The following guidelines would aid in implementing the programme:

- The programme must be re-scheduled to allow for more time to practice skills.

- Study guides must be revised and be more comprehensive.

- Weekly discussions with the programme coordinator will aid understanding and problemsolving.

- Memoranda for certain assignments will help the contract tutor to allocate more reliable marks.
- An orientation session must be implemented before the annual start of the programme.

A selection programme for contract tutors must be implemented to eliminate poor role models. Students must apply for the position of contract tutors and selection criteria must be determined.

The peer group co-ordinator must play a bigger role in prevention of racial/language and personality conflict.

- Weekly discussions with the students and individual meetings with contract students will aid problemsolving.

- Allowance must be made for changing of groups in case of personality clashes.

- The financial incentive for contract tutors should continue as it motivates them to prepare better for each session, as it is regarded as a business transaction.

- The programme should be re-evaluated annually to identify limitations and problems.

\section{RECOMMENDED RESEARCH}

Ethnographic research can be implemented regarding the nature of experiences of the different racial and cultural groups, regarding peer group guidance and supervision.

\section{CONCLUSION}

This study produced evidence that peer group guidance and supervision should be seen as a support system and a possibility for acquiring nursing skills. It is recommended that the system of peer group guidance be implemented as a permanent one with annual revision. This programme makes the student's first experience of the clinical learning environment less threatening and more rewarding.

\section{LIST OF REFERENCES}

ARMSTRONG, M 1988: A handbook of personnel management practice; $3^{\text {rd }}$ edition. London: Kogan Page.

BASSETT, CC 1999: Clinical supervision: A guide to implementation. London: NT Books.

BIEHLER, RF \& SNOWMAN, J 1997: Psychology applied to teaching. 
New York: Houton Miffin.

BOTES, AC 1986: Die oriënteringsprogram as komponent van professionele sosialisering in die verpleegkunde. Auckland Park: Randse Afrikaanse Universiteit. (M. Cur.-verhandeling).

BOUD, D 1995: Enhancing learning through self-assessment. London: Kogan.

BURNS, N \& GROVE, SK 1999: Understanding nursing research; $2^{\text {nd }}$ edition. Philadelphia: WB Saunders.

CARLSON, S; KOTZE, WJ \& VAN ROOYEN, D 2003: Accompaniment needs of first year nursing students in the clinical learning environment. Curationis, 26(2):30-39.

CHABELI, MM 2001: Alternative assessment and evaluation methods in clinical nursing education. Monograph IV. Internal publication. Auckland Park: Rand Afrikaans University.

CHABELI, MM 2001: A model to facilitate reflective thinking in clinical nursing education. Auckland Park: Rand Afrikaans University. (D Cur Thesis).

COLE, A 2002: Someone to watch over you. Nursing Times, 98(23):22-24.

CRESWELL, JW 1994: Research design: Qualitative and quantitative approaches. London: Sage.

DEMOCRATIC NURSING ORGANISATION OF SOUTH AFRICA 1998:

Ethical standards for nurse researchers. Pretoria: DENOSA.

DU PLESSIS, DW 1993: Voortgesette professionele opleiding vir vroedvroue. Auckland Park: Randse Afrikaanse Universiteit. (D Cur proefskrif).

FAUGIER, J \& BUTTERWORTH, T 1994: Clinical supervision: A position paper. Manchester: University of Manchester.

GIORGI, A ed. 1985: Phenomenology and psychological research. Pittsburgh: Duquine University Press.

HELLRIEGEL, D; JACKSON, ES; SLOCUM, J \& STAUDE, G 1999: Management. South African Edition: Oxford University Press.

JONES, MC \& JOHNSTON, DW 1997: Distress, stress and coping in first year student nurses. Journal of Advanced Nursing, 26(45):475-482.

JOUBERT, A 1989: Die rol van kliniese onderrig in die professionele sosialisering van student verpleegkundiges. Bloemfontein: Universiteit van die Oranje Vrystaat.

KELL, J 2002: Editorial: Nursing Times, 98(23):29.

KLOPPER, HC 2000: Nursing education - A reflection; $2^{\text {nd }}$ edition. Pretoria: Amabukhu.

KREFTING, L 1991: Rigor in qualitative research: The assessment of trustworthiness. American Journal of Occupational Therapy, 45(3):214-222.

McSHERRY, R; KELL, J \& PEARCE, P 2002: Clinical supervision and clinical governance. Nursing Times, 98(23):31.

MELLISH, JM \& BRINK, HIL 1990: Teaching the practice of nursing; $3^{\text {rd }}$ edition. Durban: Butterworths.

MELLISH, JM; BRINK, HIL \& PATON, F 1998: Teaching and learning the practice of nursing; $4^{\text {th }}$ edition. Johannesburg: Heinemann. MORSE, JM \& FIELD, PA 1996: Nursing research: The application of qualitative approaches. London: Chapman \& Hall.

MOUTON, J \& MARAIS, HC 1992: Metodologie van die geesteswetenskappe: Basiese begrippe. Pretoria: Raad vir Geesteswetenskaplike Navorsing.

NEL, ZJC 1986: Die invloed van indiensopleiding op die kwaliteit van psigiatriese verpleging van verstandelik vertraagde persone. Auckland Park: Randse Afrikaanse Universiteit. (M Cur.verhandeling).

PARKES, KR 1985: Stressful episodes reported by first year student nurses: A descriptive account. Social Science \& Medicine, 20(9):945-953.

VAN DEN BERG, RH 1984: Die verpleegkundige se gebruik van haarself in die begeleidingsproses van verpleging. Pretoria: Universiteit van Suid-Afrika (D. Litt. et Phil-proefskrif). 